\title{
Assessing the quality of sewage sludge as an agricultural soil amendment in Mediterranean habitats
}

\author{
Dany Romanos ${ }^{1,2}\left(\right.$ Nabil Nemer $^{2} \cdot$ Yara Khairallah $^{1} \cdot$ Marie Thérèse Abi Saab $^{3}$
}

Received: 21 April 2019 / Accepted: 22 October 2019 / Published online: 3 November 2019

(C) The Author(s) 2019

\begin{abstract}
Purpose Municipal sewage sludge generated from three operational wastewater treatment plants, located in the Bekaa valley of Lebanon, was assessed for its potential use as agricultural soil amendment.

Methods Sludge samples were taken from three treatment plants located in the villages of Iaat, Ablah and Joub Jannine during the summer season of 2018, from June to September, on a monthly basis. The evaluation was based on characterizing the physicochemical parameters such as the metal content, the pathogenic microorganisms (Salmonella, E.Coli, Staphylococcus aureus, Helminth eggs, Ascaris, Acinetobacter) and the phytotoxicity-stability indicators of the sludge samples.

Results The obtained results were compared to the Lebanese guidelines for sludge reuse in agriculture. For the physicochemical analysis, all the samples showed a possibility to be used in agriculture due to the high content of minerals and organic matter. Considering the metal content of sludge, Iaat and Ablah sludge were classified as Class A according to the Lebanese guidelines; however, sludge from Joub Janine was classified as B due to its high content of zinc that exceeded the limit of $700 \mathrm{ppm}$. Helminth eggs and Salmonella were absent in the sludge samples. Pathogenic organisms, mainly E. coli, were detected in Iaat dry sludge, Staphylococcus aureus was present in Joub Jannine sludge and Acinetobacter in Ablah station (>100 CFU/100 g).

Conclusion It is recommended to submit the sludge which did not meet the required criteria, for further treatments, particularly the composting process to reduce the metal content and pathogenic microorganisms for a safer reuse in agriculture.
\end{abstract}

Keywords Wastewater treatment $\cdot$ Sludge $\cdot$ Heavy metals $\cdot$ Physicochemical parameters $\cdot$ Pathogenic microorganisms

Dany Romanos

danny_romanos@hotmail.com

Nabil Nemer

nabilnemer@usek.edu.lb

Yara Khairallah

yara.khairallah@hotmail.com

Marie Thérèse Abi Saab

mtabisaab@lari.gov.lb

1 Soil, Fertilizers and Plants Unit, Faculty of Agricultural and Food Sciences, Lebanese Agricultural Research Institute, P.O. Box 90-1965, Fanar, Lebanon

2 The Holy Spirit University of Kaslik, P.O. Box 446, Kaslik, Lebanon

3 Climate and Water Unit, Lebanese Agricultural Research Institute, P.O. Box 90-1965, Fanar, Lebanon

\section{Introduction}

Nowadays, the wastewater treatment plants have been expanding. These plants not only treat water, but also give rise to a major waste problem since a large volumes of organic waste materials are continuously produced (Odlare et al. 2015). Management of the solids or sludge created by the treatment processes is a big challenge (Minari et al. 2017). In Ireland, the authorities are still making changes in the code of good practices concerning sewage sludge disposal (CRE 2013). As for the United Kingdom, complementary directives for the code of practices are declared in order to assist the farmers of the use of sewage sludge as soil amendments (Environment Agency 2018).

Sewage sludge is the organic by-product of wastewater treatment (Binh 2017). The sludge composition mainly consists of organic matter and nutrients (Moretti et al. 2015). However, its content is very variable, since it depends on the source of the sewage treatment process and the seasonality 
(Wyrwicka and Urbaniak 2018). A large volume of generated sewage sludge makes its disposal a problem. One proposed solution is its reuse as an agricultural soil amendment. The main advantage of using such recycled organic wastes is providing a free or low-cost fertilizer rich in organic matter, nutrients and sometimes lime (Binh 2017; Bittencourt et al. 2014).

In Parana, Brazil, the agricultural uses of sludge is expanding and a recent study showed that sludge application provide $88 \%$ of limestone, $74 \%$ of $\mathrm{N}, 73 \%$ of $\mathrm{P}_{2} \mathrm{O}_{5}$, and $35 \%$ of $\mathrm{K}_{2} \mathrm{O}$ for fertilizing crops (Bittencourt et al. 2014). In Spain, a 16-year long-term study of soil amendment with sewage sludge showed an enhancement of soil properties proportionally to the doses/frequency of application (Roig et al. 2012). In Great Britain, sewage sludge is used to increase the fertility of some infertile forestry areas (Moffat 2006). In the semi-arid Mediterranean region of Tunisia, successive amendment of sewage sludge enhanced microbial biomass and enzyme activities along with improving soil fertility (Hamdi et al. 2019).

In Lebanon, through the project UTF/LEB/019/LEB "Reuse of Treated Effluent and Sludge", the Food and Agricultural Organization of the United Nations (FAO-UN) has assisted, in 2010, in the development of guidelines for the use of sludge generated from wastewater treatment plants in agriculture (FAO 2010). However, till now, both technical and institutional challenges have not been fully met to optimize the use of sludge in agriculture. In addition, the quality of generated local sludge has still not been assessed anywhere in the country (USAID 2013). The local sludge is discarded randomly, leading to environment contamination, while it could be used in agriculture as an alternative to the use of intensive mineral fertilizers. Less mineral fertilizers would help the farmers, lowering the cost of agricultural inputs and thus getting a better income from crop production (Kotschi 2013).

The aim of this study is to assess the Lebanese local sludge quality as compared to the legislation values for sludge reuse in agriculture. This paper presents the characterization of local sludge by analyzing the physicochemical parameters, metal content, stability, pathogenic contaminants and phytotoxicity index, which will help understand the benefits and risks of using the local sludge in agriculture.

\section{Materials and methods}

\section{Sample collection}

Thirty-six samples of sewage sludge were collected from three wastewater treatment plants (WWTP) located in the Bekaa valley of Lebanon. Particularly, 12 random samples were taken from each plant from June to September of 2018 in the summer season. The plain of the Bekaa is well known by its agriculture area that constitutes the main crop and food production contributor in Lebanon; at the same time, this plain is highly urbanized and has a number of industrial factories. The first WWTP is located in Iaat village $\left(34.0375^{\circ} \mathrm{N}, 36.1754^{\circ} \mathrm{E}\right)$ generating approximately $24 \mathrm{~m}^{3}$ of sludge per day. The second WWTP is located in Ablah village $\left(33.8669^{\circ} \mathrm{N}, 35.9594^{\circ} \mathrm{E}\right)$ with about $57 \mathrm{~m}^{3}$ of sludge production per day. The third WWTP is located in Joub Jannine $\left(33.6328^{\circ} \mathrm{N}, 35.7819^{\circ} \mathrm{E}\right)$ and generates $52 \mathrm{~m}^{3}$ of sludge per day (USAID 2013). Iaat and Joub Jannine wastewater treatment plants use the solar thermal treatment in addition to liming, to stabilize the sludge, while Ablah station has a special digester to treat the sludge. The major part of this sludge is sent to a landfill. Few are reused by some farmers in their land without any sanitation control.

The collected sludge samples were transferred to the laboratories of the Lebanese Agricultural Research Institute, at a temperature of $4{ }^{\circ} \mathrm{C}$ for necessary analysis. Each sample was analyzed in three replicates.

\section{Physicochemical and metal characterization}

Dry and organic matter contents were characterized in sludge samples; $10 \mathrm{~g}$ of each sample was transferred to special containers and dried in an oven at $105^{\circ} \mathrm{C}$. After $24 \mathrm{~h}$, the percentage of dry matter was calculated by subtracting the dry weight from the fresh one and then calculating the percentage.

Then, the total organic matter content was calculated from the oven-dried samples after calcination in the oven at $550{ }^{\circ} \mathrm{C}$ for $24 \mathrm{~h}$. The total organic carbon was estimated as the half content of the organic matter, as reported in Zhao et al. (2016).

The $\mathrm{pH}$ and electrical conductivity (EC) were also determined in sludge samples. The samples were mixed with distilled water in 1:5 ratios (w/w) for $1 \mathrm{~h}$. After decantation, when the supernatant was separated from the settled material, the $\mathrm{pH}$ and the EC were measured using Thermo scientific Orion Star $\mathrm{pH} /$ conductivity meter, following the same procedure as Samara et al. (2017).

A microwave digestion technique was used to analyze the following parameters: nitrogen, phosphorus, potassium, calcium, magnesium, and sodium (Bittencourt et al. 2014). Therefore, $1 \mathrm{~g}$ of dried sludge was digested with Piranha solution (mixture $9 \mathrm{~mL}$ of sulfuric acid $\left(\mathrm{H}_{2} \mathrm{SO}_{4}\right)$ and $3 \mathrm{~mL}$ hydrogen peroxide $\left(\mathrm{H}_{2} \mathrm{O}_{2}\right)$ in a microwave digester (Milestone, Ethos easy) at a temperature of $200{ }^{\circ} \mathrm{C}$ and a pressure of $100 \mathrm{bar}$ for $1 \mathrm{~h}$. Then, nitrogen was determined by the Kjeldahl titration method (Bittencourt et al. 2014). Phosphorus content was obtained by Olsen method, as reported in Suchkova et al. (2014). Potassium and sodium elements were determined by flame photometer detector. Calcium, 
magnesium and heavy metals (copper, zinc, iron, boron, cadmium, chromium, lead, aluminum and mercury) were determined by atomic absorption technique using ICE 3000 series AA spectrometers (Thermo Fisher Scientific) (Samara et al. 2017).

\section{Microbial analysis}

As proposed by the Lebanese guidelines for sludge reuse, the two main microorganisms that can affect the quality of the sludge are: Salmonella and Escherichia coli. The detection of Salmonella was conducted following ISO 6579 method (ISO 2002), while the quantification of $E$. coli was elaborated according to ISO 16649-2 method (ISO 2001).

In addition, helminth eggs were also detected following the four steps as reported in Amoah et al. (2018): the first step was "desorption" to release the eggs from solids by adding ammonium bicarbonate $(119 \mathrm{~g} / \mathrm{L})$ to the sample and blending at high speed; secondly, "flotation", by sieving samples at $100 \mu \mathrm{m}$ and then $20 \mu \mathrm{m}$ to recover the eggs: the content on the $100 \mu \mathrm{m}$ sieve were washed under pressure of hot tap water and the contents on $20 \mu \mathrm{m}$ sieve were centrifuged at $3000 \mathrm{rpm}$ for $10 \mathrm{~min}$; third step was "extraction": supernatants were discarded and to the bead, zinc sulfate solution (specific gravity 1.30) was added, remixed and centrifuged for $10 \mathrm{~min}$ at $2000 \mathrm{rpm}$. The supernatant was sieved in a $20 \mu \mathrm{m}$ mesh sieve and new contents were centrifuged one more time at $3000 \mathrm{rpm}$ for another $10 \mathrm{~min}$ to remove the impurities. Finally, the detected eggs through the microscope in the final supernatants and in the pellets were incubated with $0.1 \mathrm{~N}$ sulfuric acid to develop the larvae in suitable conditions for 28 days.

\section{Stability and phytotoxicity indices}

The measurement of the stability of sludge is an indicator of the bacterial activity. The samples were re-wet (30-50\% moisture) and filled in the Dewar self-heating test in an isolated cup to test the daily maximum and minimum temperature heated by the existing organic matter. The self-heating test took 5 days to reach a stabilized temperature according to Alvarenga et al. (2016), considering the five levels of stability (Table 1).

According to Fuentes et al. 2004, the estimation of sludge phytotoxicity was done by performing a germination test with cress (Lepidium sativum) seeds. A mixture of dry sludge and distilled water with 1:10 ratio was mixed for $1 \mathrm{~h}$. After centrifugation and filtration of the supernatant, the sludge extract (1-5 mL) was added to a Petri dish covered with a filter paper. Ten seeds of cress were laid on the filter paper of each Petri dish. Distilled water was used instead in the control. All the dishes were incubated in dark at a
Table 1 Levels of sludge stability (Abfall 1995)

temperature of $25{ }^{\circ} \mathrm{C}$ for 6 days. Each sample was done in triplicate.

\section{Calculation of germination index}
$\%$ RSG = (number of seed germinated in sludge extract)/ (number of seed germinated in control) $\times 100$,

$\% \mathrm{RRG}=($ mean root length in sludge extract $) /$ (mean root length in control) $\times 100$,

$\% \mathrm{GI}=(\mathrm{RSG} \times \mathrm{RRG}) / 100$,

where $R S G$ is the relative seed germination and $R R G$ is the relative root growth.

\section{Results and discussion}

\section{Physicochemical and metal characteristics}

The results of the physicochemical analysis of sludge samples collected from the different stations are presented in Table 2 . The mean $\mathrm{pH}$ values in all stations were between $6.50 \pm 0.12$ and $7.057 \pm 0.05$, which indicates a slightly acid to neutral $\mathrm{pH}$ usually due to the calcium and magnesium content (Mtshali et al. 2014). The highest electrical conductivity (EC) was reported for Ablah sludge with a mean value of $4.92 \pm 0.27 \mathrm{~ms} / \mathrm{cm}$, while the lowest EC was recorded for Iaat sludge $(2.25 \pm 0.64 \mathrm{~ms} / \mathrm{cm})$. The higher EC could be mostly due to the elevated level of sodium found in sludge (Fuentes et al. 2004). The collected sewage sludge contained considerable concentration of nitrogen and phosphorus. The mean amounts of nitrogen in sewage sludge varied between $1.69 \pm 0.19 \%$ in Ablah to $2.91 \pm 0.34 \%$ in Joub Jannine and $2.43 \pm 0.75 \%$ in Iaat (Table 2). As for phosphorus, its levels fluctuated between $3.93 \pm 0.21 \%$ in Joub Jannine, $1.85 \pm 0.19$ $\%$ in Ablah and $1.84 \pm 0.22 \%$ in Iaat on a dry matter basis (Table 2). Total phosphorus content of the studied sludge was in general high compared to other forms of organic 
Table 2 Physicochemical characterization of sludge from the three treatment stations (D.M: dry matter, M: moisture, O.M: organic matter, EC: electrical conductivity) (mean $\pm \mathrm{SD}, n=12$ )

\begin{tabular}{|c|c|c|c|c|c|c|c|c|c|}
\hline & \multirow[b]{2}{*}{ Min } & \multicolumn{3}{|l|}{ IAAT } & \multicolumn{3}{|l|}{ Joub Jannine } & \multicolumn{2}{|l|}{ Ablah } \\
\hline & & Mean \pm SD & $\operatorname{Max}$ & Min & Mean \pm SD & Max & Min & Mean \pm SD & Max \\
\hline $\mathrm{pH}$ & 6.35 & $6.50 \pm 0.12$ & 6.64 & 6.71 & $6.74 \pm 0.03$ & 6.78 & 6.97 & $7.057 \pm 0.05$ & 7.13 \\
\hline $\mathrm{EC}(\mathrm{ms} / \mathrm{cm})$ & 1.51 & $2.25 \pm 0.64$ & 3.09 & 2.69 & $2.81 \pm 0.09$ & 2.95 & 4.47 & $4.92 \pm 0.27$ & 5.38 \\
\hline $\mathrm{N} \%$ & 1.44 & $2.43 \pm 0.75$ & 3.39 & 2.55 & $2.91 \pm 0.34$ & 3.42 & 1.42 & $1.69 \pm 0.19$ & 1.92 \\
\hline $\mathrm{P}_{2} \mathrm{O}_{5} \%$ & 1.44 & $1.84 \pm 0.22$ & 2.13 & 3.48 & $3.93 \pm 0.21$ & 4.13 & 1.51 & $1.85 \pm 0.19$ & 2.17 \\
\hline $\mathrm{K}_{2} \mathrm{O} \%$ & 0.22 & $0.31 \pm 0.05$ & 0.42 & 0.40 & $0.42 \pm 0.02$ & 0.45 & 0.41 & $0.45 \pm 0.03$ & 0.48 \\
\hline ASH \% & 28.16 & $36.44 \pm 8.1$ & 46.83 & 40.90 & $43.98 \pm 1.62$ & 45.73 & 46.78 & $48.37 \pm 0.9$ & 49.44 \\
\hline D.M \% & 94.1 & $95.55 \pm 1.23$ & 97.37 & 93.10 & $93.91 \pm 0.55$ & 94.42 & 93.83 & $94.79 \pm 0.84$ & 95.69 \\
\hline M \% & 2.63 & $4.44 \pm 1.23$ & 5.90 & 5.58 & $6.09 \pm 0.55$ & 6.90 & 4.31 & $5.22 \pm 0.78$ & 6.17 \\
\hline O.M \% & 53.17 & $63.55 \pm 8.1$ & 71.84 & 54.27 & $56.01 \pm 1.62$ & 59.10 & 50.56 & $51.62 \pm 0.9$ & 53.22 \\
\hline C \% & 29.54 & $35.30 \pm 4.5$ & 39.91 & 30.15 & $31.11 \pm 0.9$ & 32.83 & 28.09 & $28.68 \pm 0.5$ & 29.56 \\
\hline $\mathrm{C} / \mathrm{N}$ & 11.54 & $15.46 \pm 3.55$ & 22.98 & 9.00 & $10.86 \pm 1.37$ & 12.18 & 14.99 & $17.16 \pm 2.13$ & 20.27 \\
\hline $\mathrm{CaO} \%$ & 2.57 & $3.93 \pm 1.13$ & 5.96 & 4.13 & $4.88 \pm 0.56$ & 5.65 & 3.38 & $4.24 \pm 0.54$ & 4.85 \\
\hline $\mathrm{MgO} \%$ & 0.46 & $0.60 \pm 0.12$ & 0.76 & 0.75 & $0.85 \pm 0.07$ & 0.94 & 0.72 & $0.90 \pm 0.24$ & 1.31 \\
\hline $\mathrm{Na} \mathrm{ppm}$ & 102.12 & $190.38 \pm 98.5$ & 373.7 & 237.5 & $264.53 \pm 26.3$ & 320.83 & 3612.3 & $4371.62 \pm 668.1$ & 5443.73 \\
\hline
\end{tabular}

fertilizers. Although high amounts of phosphorus and nitrogen were recorded in the samples, the potassium content of the sludge was relatively low which was in agreement with the findings of Bittencourt et al. (2014).

Desired value of moisture content must range between 40 and $60 \%$ which is acceptable by the Lebanese guidelines (FAO 2010). In our case of study, initial moisture content was between 4 and $6 \%$ (Table 2), which is related to the drying methods used in the treatment of wastewater (Shanahan et al. 2010; USAID 2013) Moisture loss is linked to the high temperature method of treatment (Nayak and Kalamdhad 2014).

The obtained mean values of organic matter were $51.62 \pm 0.9 \%$ in Ablah, $56.01 \pm 1.62 \%$ in Joub Jannine and $63.55 \pm 8.1 \%$ in Iaat (Table 2). It is well known that sludge's organic matter is the component key to its successful use as organic amendment (Reuter 1993). Organic matter has an important role in soil such as increasing the stability of the formed aggregate, reducing the bulk density, and upholding better infiltrations of water (Roig et al. 2012). In addition, organic matter positively influences the storage and the yield of nutrient, the activity and the diversity of soil biota (Deepesh et al. 2016).

As for the $\mathrm{C} / \mathrm{N}$ ratio, many authors have mentioned that an ideal ratio for the maturity of the organic material would be between 15 and 30 (Binh 2017). IAAT and Ablah stations reached a ratio of, respectively, $15.46 \pm 3.55$ and $17.16 \pm 2.13$ (Table 2). For Joub Jannine, the carbon to nitrogen ratio was lower at $10.86 \pm 1.37$ (Table 2). A lower $\mathrm{C} / \mathrm{N}$ ratio increases leaching and consequently loss of nitrogen and volatilization of ammonia. A higher $\mathrm{C} / \mathrm{N}$ ratio indicates a limited mobilization of nitrogen; nevertheless, an availability for a later period of growth (Bhatt et al. 2015). When the $\mathrm{C} / \mathrm{N}$ ratio is too low, the resultant product will not help improve the soil structure (Parvaresh and Alidadi 2004). On the other hand, micronutrients are also present to a variable extent based on the origin and treatments of sludge. Micronutrients such as calcium oxide and magnesium oxide were present in noteworthy concentrations and can counteract acidification and enhance the outcome of other fertilizers by adjusting soil pH when applied (Table 2) (Kotschi 2013).

The following metal elements were studied: $\mathrm{Pb}, \mathrm{Cr}, \mathrm{Ni}$, $\mathrm{Zn}, \mathrm{Al}, \mathrm{Fe}, \mathrm{Cu}, \mathrm{Cd}, \mathrm{B}, \mathrm{Mo}, \mathrm{Co}, \mathrm{Mn}$ and $\mathrm{Hg}$. The obtained results revealed that the values were within the admissible limits of sludge category A, with no restrictions on use, as proposed by the Lebanese Guidelines (Table 3) (FAO 2010). However, Zn element slightly exceeded the limit value of category A (700 ppm) in both Ablah and Joub Jannine, which could be related to deposits from corrosion of pipes and plumbing components (Shanahan et al. 2010). Therefore, the sludge generated from those stations must be considered as Category B (FAO 2010). It should be mentioned that, according to the Lebanese Guidelines, the main difference between categories A and B is that the sludge category B cannot be applied in public areas and parks. However, sludge belonging to both categories can be applied for agricultural use except for the production of vegetables that are eaten raw.

Accordingly, it is important to highlight that the properties and the composition of the investigated sludge depend highly on its origin. Furthermore, the treatment methods contribute to differences in sludge characteristics (Rehman et al. 2018). Consequently, the physicochemical and metal characteristics of the analyzed sludge of the three WWTPs confirm that it can be considered as a significant fertilizer 
Table 3 Micronutrient and heavy metal contents in sludge (values expressed in ppm except for Fe in percentage) $($ mean $\pm \mathrm{SD}, n=12)$

\begin{tabular}{|c|c|c|c|c|c|c|c|c|c|c|}
\hline & & IAAT & & & Joub Jannine & & & Ablah & & Threshold $^{\mathrm{a}}$ \\
\hline & Min & Value $\pm S D$ & $\operatorname{Max}$ & Min & Value $\pm S D$ & $\operatorname{Max}$ & Min & Value \pm SD & Max & \\
\hline $\mathrm{Pb}$ & 6.1 & $20.75 \pm 8.9$ & 31.2 & 4.22 & $31.12 \pm 5.51$ & 36.83 & 6.57 & $9.83 \pm 2.16$ & 150 & 36.30 \\
\hline $\mathrm{Cr}$ & 31.9 & $49.27 \pm 9.6$ & 64.1 & 46.43 & $62.29 \pm 2.07$ & 65.45 & 49.26 & $55.03 \pm 3.44$ & 250 & 60.88 \\
\hline $\mathrm{Ni}$ & 11.5 & $19.19 \pm 4.3$ & 30.5 & 16.39 & $28.014 \pm 1.38$ & 30.50 & 16.79 & $21.88 \pm 1.7$ & 125 & 27.73 \\
\hline $\mathrm{Zn}$ & 373.3 & $505.71 \pm 97.53$ & 767.1 & 436.92 & $726.11 \pm 20.75$ & 751.17 & 448.74 & $738.41 \pm 22.25$ & 700 & 774.1 \\
\hline $\mathrm{Al}$ & 6440.8 & $9131.63 \pm 2303.02$ & 11623.3 & 7798.24 & $17029.951 \pm 23314.5$ & 45927.8 & 7498.81 & $11639.99 \pm 15673.23$ & NI & 43486.9 \\
\hline $\mathrm{Fe}$ & 0.2 & $0.36 \pm 0.09$ & 2.9 & 0.42 & $2.67 \pm 0.23$ & 2.94 & 0.38 & $0.46 \pm 0.05$ & NI & 2.81 \\
\hline $\mathrm{Cu}$ & 56.3 & $89.03 \pm 15.4$ & 149.6 & 92.99 & $130.55 \pm 18.16$ & 148.52 & 95.03 & $142.11 \pm 4.43$ & 375 & 151.31 \\
\hline $\mathrm{Cd}$ & 0.0 & $0.49 \pm 0.45$ & 1.2 & 0.00 & $0.04 \pm 0.01$ & 0.42 & 0.00 & 0.00 & 5 & 0.13 \\
\hline B & 0.0 & $17.73 \pm 18.2$ & 39.5 & 0.00 & $0.09 \pm 0.06$ & 0.16 & 0.00 & 0.00 & NI & 0.16 \\
\hline Mo & 34.8 & $67.56 \pm 24.2$ & 135.0 & 46.92 & $97.24 \pm 34.07$ & 135.04 & 44.93 & $73.96 \pm 27.27$ & NI & 97.68 \\
\hline Co & 7.9 & $14.84 \pm 2.1$ & 17.1 & 8.02 & $8.61 \pm 0.62$ & 19.14 & 8.74 & $15.34 \pm 1.2$ & NI & 18.06 \\
\hline $\mathrm{Mn}$ & 60.4 & $111.34 \pm 41.02$ & 176.5 & 113.13 & $146.24 \pm 6.94$ & 177.45 & 115.33 & $168.79 \pm 8.63$ & NI & 181.59 \\
\hline $\mathrm{Hg}$ & 0.5 & $0.51 \pm 0.11$ & 1.6 & 0.34 & $1.01 \pm 0.16$ & 1.31 & 0.42 & $1.22 \pm 0.21$ & 4 & 1.36 \\
\hline
\end{tabular}

NI not indicated

${ }^{a}$ Sludge class as per Lebanese guidelines for sludge reuse

replacement for major plant nutrients to be applied only on crops that are not eaten raw (Dai et al. 2006).

\section{Microbiological characteristics of sludge}

Besides its physicochemical characteristics, sewage sludge's origin and its biological contamination affect the suitability, quantity and availability of nutrients in crop growth. Nonactivated sewage sludge revealed a high count of viable $E$. coli in the IAAT station, Staphylococcus aureus in Joub Jannine station and Acinetobacter spp. in Ablah station. Both Salmonella and helminth eggs were absent in all stations (Table 4).

The sources of sludge pathogen contamination are human/animal wastes and wastes from biological laboratory analysis, food processing, and during some treatment of wastewater. According to the EPA (Environmental Protection Agency), pathogens in sludge are distinguished by four categories: viruses, bacteria, parasites, and fungi (Fijalkowski et al. 2017).

To overcome the risk of biological contamination correlated with sludge disposal, various processes with variable degrees of pathogen reduction can be implemented. Composting is the easiest procedure; stable humus can be produced under aerobic thermophilic conditions for more than 15 days at $55^{\circ} \mathrm{C}$ (Department of the Environment 1996). Nonetheless, not all pathogens can be destroyed. Another alternative is chemical stabilization, such as using lime, chlorine and, its compound, ozone, etc. (Rocha et al. 2016). Furthermore, high $\mathrm{pH}$ treatment can be applied for several hours. The safest and fastest method that can be used is solar heat treatment of sludge (Shanahan et al. 2010).

\section{Stability and phytotoxicity}

The stability of the sludge sample is assessed by the Dewar self-heating tests, so that the capacity of the sludge to reheat
Table 4 Microbiological evaluation of sludge $($ mean $\pm \mathrm{SD}, n=12)$

\begin{tabular}{lllll}
\hline CFU/g & IAAT & Joub Jannine & Ablah & Limit value $^{\mathrm{a}}$ \\
\hline $\begin{array}{l}\text { Salmonella } \\
\text { Helminth eggs }\end{array}$ & Absent & Absent & Absent & $\begin{array}{l}3 / 4 \mathrm{~g} \\
\end{array}$ \\
& Absent & Absent & Absent & $\begin{array}{c}<1 / 5 \text { grams } \\
\text { total dry }\end{array}$ \\
& & & & solids \\
E. Coli & $>100.000$ & Absent & Absent & $<1000$ \\
Staphylococcus aureus & Absent & $>100.000$ & Absent & NI \\
Acinetobacter spp. & Absent & Absent & $>100.000$ & NI \\
\hline
\end{tabular}

NI not indicated

${ }^{\text {a }}$ Sludge class as per Lebanese guidelines for sludge reuse 
Table 5 Stability and phytotoxicity parameters

\begin{tabular}{llll}
\hline Station & $\begin{array}{l}\text { Dewar self- } \\
\text { heating test } \\
\left({ }^{\circ} \mathrm{C}\right)\end{array}$ & $\begin{array}{l}\text { Class of } \\
\text { stability }\end{array}$ & Germination index (\%) \\
\hline Iaat & $59.1 \pm 0.24$ & II & $27.78 \pm 1.7$ \\
Ablah & $57.2 \pm 0.31$ & II & $32.27 \pm 0.9$ \\
Joub Jannine & $55.8 \pm 0.22$ & II & $32.01 \pm 1.9$ \\
\hline
\end{tabular}

can be evaluated as reported in Table 5. The evolution of the temperature was recorded until the production of heat ceased. The class of stability was recorded according to the maximum temperature reached: class $\mathrm{I}>60{ }^{\circ} \mathrm{C}, 50^{\circ} \mathrm{C}<$ class II $>60{ }^{\circ} \mathrm{C}$ and $40{ }^{\circ} \mathrm{C}<$ class III $>50{ }^{\circ} \mathrm{C}$. Due to biological activity and a neutral $\mathrm{pH}$, the temperature was raised to class II category which showed an unstable sludge. Therefore, the germination index showed a low percentage owing to the same reason of high microbiological activity existing in the sludge which prevents the growth of roots (Table 5). The non-stability of sludge and the relatively high phytotoxicity indicate the immaturity of the sludge (Alvarenga et al. 2015).

\section{Conclusion}

Sewage sludge utilization as a means of waste disposal is gaining attention nowadays. However, characterization of sewage sludge is critical before any land application (Harrison et al. 2003). Sewage sludge characterization helps determine the magnitude of nutrients for soil supplementation and enables the investigation of the presence of pollutants such as heavy metals and microbial pathogens (Bhatt et al. 2015). In this study, physicochemical and microbiological characterizations of the sludge generated from three stations in the Bekaa valley of Lebanon were performed.

The results indicated that sewage sludge had high fertilizing values for essential macronutrients (phosphorus, nitrogen, and calcium oxide) and organic matter. However, unfortunately, it was contaminated with E. coli, Staphylococcus aureus and Acinetobacter spp. Thus, it should not be disposed on land unless it has undergone pathogen reduction. As for the heavy metals, they were all under the limits set by the Lebanese guidelines on sludge reuse in Lebanon (FAO 2010). The microbiological activity in all samples affected the stability of sludge, resulting in a low germination rate and thus restricting its use in agriculture. It is important to improve the stabilization management of the Lebanese sludge through the reduction of the microbiological contamination under the limits to profit from using the sludge in agriculture. Further research is needed to explore the impact of using local sludge on soil and crops.
Acknowledgments I would like to express my very great appreciation to Prof. Michel Afram, CEO of the Lebanese Agricultural Research Institute for his valuable help and encouragement. Without his support, this research would not have been done.

Open Access This article is distributed under the terms of the Creative Commons Attribution 4.0 International License (http://creativeco mmons.org/licenses/by/4.0/), which permits unrestricted use, distribution, and reproduction in any medium, provided you give appropriate credit to the original author(s) and the source, provide a link to the Creative Commons license, and indicate if changes were made.

\section{References}

Abfall L (1995) Qualitatskriterien und Anwendungsempfehlungen fur Kompost. Erich Schmidt Verlag, Berlin

Alvarenga P, Mourinha C, Farto M, Santos T, Palma P, Sengo J, Morais M-C, Cunha-Queda C (2015) Sewage sludge, compost and other representative organic wastes as agricultural soil amendments: benefits versus limiting factors. Waste Manag 40:44-52. https:// doi.org/10.1016/j.wasman.2015.01.027

Alvarenga P, Mourinha C, Farto M, Palma P, Sengo J, Morais M-C, Cunha-Queda C (2016) Quality assessment of a battery of organic wastes and composts using maturity, stability and enzymatic parameters. Waste Biomass Valor 7:455-465. https://doi. org/10.1007/s12649-015-9468-y

Amoah ID, Reddy P, Seidu R, Stenström TA (2018) Concentration of soil-transmitted helminth eggs in sludge from South Africa and Senegal: a probabilistic estimation of infection risks associated with agricultural application. J Environ Manag 206:1020-1027. https://doi.org/10.1016/j.jenvman.2017.12.003

Bhatt P, Mathur N, Singh A, Bhatnagar P (2015) Recycled sewage sludge: a step to sustainable agriculture. Int J Chem Sci 13:1611-1620

Binh NT (2017) A study of sewage sludge composting, utilization of compost and nitrogen dynamics in plant-soil system. A thesis, Okayama University, Japan

Bittencourt S, Serrat BM, Aisse MM, Gomes D (2014) Sewage sludge usage in agriculture: a case study of its destination in the Curitiba Metropolitan Region, Paraná, Brazil. Water Air Soil Pollut 225:2074. https://doi.org/10.1007/s11270-014-2074-y

CRE (2013) The management of sewage sludge in Ireland. CRE, St. Louis

da Rocha MCV, Barés ME, Braga MCB (2016) Quantification of viable helminth eggs in samples of sewage sludge. Water Res 103:245255. https://doi.org/10.1016/j.watres.2016.07.039

Dai JY, Chen L, Zhao JF, Ma N (2006) Characteristics of sewage sludge and distribution of heavy metal in plants with amendment of sewage sludge. J Environ Sci (China) 18:1094-1100. https:// doi.org/10.1016/S1001-0742(06)60045-4

Deepesh V, Verma VK, Suma K, Ajay S, Gnanavelu A, Madhusudanan M (2016) Evaluation of an organic soil amendment generated from municipal solid waste seeded with activated sewage sludge. J Mater Cycles Waste Manag 18:273-286. https://doi.org/10.1007/ s10163-014-0329-8

Department of the Environment (1996) Code of Practice For Agriculture Use Of Sewage Sludge, DEFRA. https://doi. org/10.1016/0043-1354(85)90111-3

Environment Agency, Department for Environment Food and Rural Affairs (2018) Guidance: Sewage sludge in agriculture: code of practice for England, Wales and Northern Ireland. https://www. gov.uk/government/publications/sewage-sludge-in-agricultur 
e-code-of-practice/sewage-sludge-in-agriculture-code-of-pract ice-for-england-wales-and-northern-ireland\#examples-of-effec tive-sludge-treatment-processes. Accessed 4 Mar 2019

FAO (2010) Wastewater reuse and sludge valorisation and reuse proposition for Lebanese guidelines on sewage sludge use in agriculture. FAO, Rome

Fijalkowski K, Rorat A, Grobelak A, Kacprzak MJ (2017) The presence of contaminations in sewage sludge. The current situation. $\mathrm{J}$ Environ Manag 203:1126-1136. https://doi.org/10.1016/j.jenvm an.2017.05.068

Fuentes A, Lloréns M, Sáez J, Aguilar MI, Ortuño JF, Meseguer VF (2004) Phytotoxicity and heavy metals speciation of stabilised sewage sludges. J Hazard Mater 108:161-169. https://doi. org/10.1016/j.jhazmat.2004.02.014

Hamdi H, Hechmi S, Khelil MN, Zoghlami IR, Benzarti S, MokniTlili S, Hassen A, Jedidi N (2019) Repetitive land application of urban sewage sludge: effect of amendment rates and soil texture on fertility and degradation parameters. Catena 172:11-20. https ://doi.org/10.1016/j.catena.2018.08.015

Harrison EZ, Waste C, Telega L, Program P (2003) Considerations for dairy farms regarding use of sewage sludges, sludge products and septage, http://cwmi.css.cornell.edu/Sludge.html

Kotschi J (2013) A soiled reputation: adverse impacts of mineral fertilizers in tropical agriculture. Heinrich-Böll-Stiftung, Berlin ISO 16649-2

Minari GD, Rosalen DL, da Cruz MCP, de Melo WJ, Alves LMC, Saran LM (2017) Agricultural management of an Oxisol affects accumulation of heavy metals. Chemosphere 185:344-350. https ://doi.org/10.1016/j.chemosphere.2017.07.008

Moffat A (2006) Use of sewage sludges and composts in forestry. For commision. https://doi.org/10.1177/1088357608329173

Moretti SML, Bertoncini EI, Abreu-Junior CH (2015) Composting sewage sludge with green waste from tree pruning. Sci Agric 72:432-439. https://doi.org/10.1590/0103-9016-2014-0341

Mtshali JS, Tiruneh AT, Fadiran AO (2014) Sewage sludge, nutrient value, organic fertilizer, soil amendment, sludge reuse, nitrogen, phosphorus; sewage sludge, nutrient value, organic fertilizer, soil amendment, sludge reuse, nitrogen, phosphorus. Resour Environ 4:190-199. https://doi.org/10.5923/j.re.20140404.02

Nayak AK, Kalamdhad AS (2014) Feasibility of composting combinations of sewage sludge, cattle manure, and sawdust in a rotary drum reactor. Environ Eng Res 19:47-57. https://doi.org/10.4491/ eer.2014.19.1.047

Odlare M, Lindmark J, Ericsson A, Pell M (2015) Use of organic wastes in agriculture. Energy Procedia 75:2472-2476. https:// doi.org/10.1016/j.egypro.2015.07.225

Parvaresh A, Alidadi H (2004) Determination of carbon/nitrogen ratio and heavy metals in bulking agents used for sewage composting. Carbon N Y 33:20-23
Rehman RA, Rizwan M, Qayyum MF et al (2018) Efficiency of various sewage sludges and their biochars in improving selected soil properties and growth of wheat (Triticum aestivum). J Environ Manag 223:607-613. https://doi.org/10.1016/j.jenvman.2018.06.081

Reuter R (1993) Sewage sludge as an organic amendment for reclaiming surface mine wastes. Student On-line J 2(7):1-6

Roig N, Sierra J, Martí E, Nadal M, Schuhmacher M, Domingo JL (2012) Long-term amendment of Spanish soils with sewage sludge: effects on soil functioning. Agric Ecosyst Environ 158:4148. https://doi.org/10.1016/j.agee.2012.05.016

Samara E, Matsi T, Balidakis A (2017) Soil application of sewage sludge stabilized with steelmaking slag and its effect on soil properties and wheat growth. Waste Manag 68:378-387. https://doi. org/10.1016/j.wasman.2017.06.016

Shanahan EF, Roiko A, Tindale NW, Thomas MP, Walpole R, Ipek KD (2010) Evaluation of pathogen removal in a solar sludge drying facility using microbial indicators. Int J Environ Res Public Health 7:565-582. https://doi.org/10.3390/ijerph7020565

Suchkova N, Tsiripidis I, Alifragkis D, Ganoulis J, Darakas E, Sawidis Th (2014) Assessment of phytoremediation potential of native plants during the reclamation of an area affected by sewage sludge. Ecol Eng 69:160-169

The International Organization for Standardization (2001) Microbiology of food and animal feeding stuffs -Horizontal method for the enumeration of b-glucuronidase-positive Escherichia coli: part 2: colony-count technique at $44^{\circ} \mathrm{C}$ using 5-bromo-4-chloro-3-indolyl b-D-glucuronide, vol 4. The International Organization for Standardization, Geneva

The International Organization for Standardization (2002) Microbiology of food and animal feeding stuffs. Horizontal method for the detection of Salmonella spp, vol 4. The International Organization for Standardization, Geneva ISO 6579

USAID (2013) Water supply and wastewater systems master plan for the Bekaa water establishment inception report

Wyrwicka A, Urbaniak M (2018) The biochemical response of willow plants (Salix viminalis L.) to the use of sewage sludge from various sizes of wastewater treatment plant. Sci Total Environ 615:882-894. https://doi.org/10.1016/j.scitotenv.2017.10.005

Zhao XL, Li BQ, Ni JP, Xie DT (2016) Effect of four crop straws on transformation of organic matter during sewage sludge composting. J Integr Agric 15:232-240. https://doi.org/10.1016/s2095 $-3119(14) 60954-0$

Publisher's Note Springer Nature remains neutral with regard to jurisdictional claims in published maps and institutional affiliations. 